\title{
Pulsatilla koreana Nakai Downregulates C/EBPs/PPAR $\gamma$ and Suppresses Fatty Acid Synthase via activation of AMPK $\alpha$ in 3T3-L1 cells
}

\author{
N. H. KIM, H. J. KIM, J. Y. IM, W. R. KWAK, Y. H. KIM', D. K. KIM², S. LIM³ AND Y. LEE*
}

Department of Oriental Pharmacy and Wonkwang-Oriental Medicines Research Institute, Wonkwang University, Iksan 570749, ${ }^{1}$ Department of College of Pharmacy, Chungnam National University, Daejeon, 305-764, ${ }^{2}$ Department of Immunology and Institute of Medical Science, Jeonbuk National University Medical School, Jeonju 561-756, ${ }^{3}$ College of Pharmacy, Catholic University of Korea, Bucheon 420-743, Republic of Korea

Kim et al.: Antiobesity effects of Pulsatilla koreana Nakai ethanol extract

\begin{abstract}
Pulsatilla koreana Nakai, or pasque flower has been used as a medicinal plant for the treatment of amoebic dysentery, malaria, and internal haemorrhoids. The extract of Pulsatilla koreana Nakai, itself, has not been yet investigated for potential antiobesity effects. In this study, the antiobesity effect was evaluated on preadipocyte differentiation of Pulsatilla koreana Nakai extracted by $70 \%$ ethanol in 3T3-L1 cells. Pulsatilla koreana Nakai ethanol extract at doses of $20 \mu \mathrm{g} / \mathrm{ml}$ significantly decreased lipid droplet accumulation, the expression of transcription factors, including CCAAT/enhancer-binding protein $\alpha, \beta, \delta$, peroxisome proliferator-activated receptor gamma and mRNA levels of fatty acid synthase. Moreover, Pulsatilla koreana Nakai ethanol extract also activated the phosphorylation of 5 ' adenosine monophosphate-activated protein kinase $\alpha$. In conclusion, Pulsatilla koreana Nakai ethanol extract suppressed preadipocyte differentiation via down-regulation of CCAAT/enhancer-binding proteins, peroxisome proliferator-activated receptor gamma, and fatty acid synthase by phosphorylation of 5'-adenosine monophosphate-activated protein kinase $\alpha$ in adipocytes. This data suggested that Pulsatilla koreana Nakai ethanol extract be further explored as a new preventive and therapeutic agent against obesity.
\end{abstract}

Key words: Pulsatilla koreana Nakai, ethanol extract, antiobesity, CCAAT/enhancer-binding protein, peroxisome proliferator-activated receptor, $5^{\prime}$ adenosine monophosphate-activated protein kinase

Obesity is a steadily increasing public health dilemma that is associated with an imbalance between energy intake and expenditure ${ }^{[1]}$. The state of being overweight or obese increases the risk of developing serious diseases such as hypertension, coronary heart disease, insulin resistance type 2 diabetes, dyslipidemia, arteriosclerosis, infertility, back pain, and some cancers ${ }^{[2]}$. These situations can be due to an altered lipid metabolism, including lipogenesis and lipolysis, and accumulation of excessive abdominal fat can induce metabolic impairments ${ }^{[3]}$. The multistep processes are related to the proliferation or differentiation of adipocytes, and fatty acid oxidation or synthesis ${ }^{[4]}$. In adipocyte differentiation, various transcriptional factors including CCAAT/enhancerbinding protein $(\mathrm{C} / \mathrm{EBP}) \alpha, \beta, \delta$, and peroxisome proliferator-activated receptor (PPAR) $\gamma$ play a role as the major regulators of adipogenesis ${ }^{[5,6]}$. C/EBP $\beta$ and $\mathrm{C} / \mathrm{EBP} \delta$ are expressed in the early phase of adipocyte differentiation and activate the expression of PPAR $\gamma$ and $\mathrm{C} / \mathrm{EBP} \alpha^{[5,7]}$. During adipogenesis, $\mathrm{C} / \mathrm{EBP} \alpha$ is involved in stimulating and maintaining the expression of PPAR $\gamma^{[6,8]}$. Additionally, the expressed genes are involved in the adipocytes phenotype and maintenance via lipid metabolic enzymes at the end of adipocytes differentiation ${ }^{[9]}$. Fatty acid synthase (FAS) as a representative key enzyme in the lipogenesis pathway, plays a role in catalysing all the enzymatic reactions involved in the conversion of acetyl CoA and malonyl CoA finally to palmitic acids ${ }^{[9,10]}$. Activation of 5'-adenosine monophosphate-activated protein kinase (AMPK), which functions as an energy status

This is an open access article distributed under the terms of the Creative Commons Attribution-NonCommercial-ShareAlike 3.0 License, which allows others to remix, tweak, and build upon the work non-commercially, as long as the author is credited and the new creations are licensed under the identical terms

Accepted 12 January 2019

Revised 04 May 2018

Received 29 April 2017

Indian J Pharm Sci 2019;81(2):219-225 
sensor of cells, inhibits fatty acid synthesis through the inactivation of acetyl CoA carboxylase, which hinders the differentiation of preadipocytes into adipocytes and down-regulates PPAR $\gamma$ expression ${ }^{[11]}$. Various herbal medicine formulas have been developed for the prevention and treatment of obesity ${ }^{[6]}$. As known a pasque flower, Pulsatilla koreana Nakai (fig. 1) is a perennial grass belonging to the family Ranunculaceae, which has traditionally been used as an herbal medicine for the treatment of amoebic dysentery, malaria, and internal haemorrhoids in Korea and $\mathrm{China}^{[12]}$. Additionally, pharmacological effects of $P$. koreana Nakai such as hypoglycaemic, antitumor, cognition-enhancing, neuroprotective, cytotoxic, and antiangiogenic activities have been reported ${ }^{[13]}$. P. koreana root contains various phytochemicals that included anemonin, protoanemonin, hederagenin, oleanane, ranunculin, oleanolic saponins, lupinetype triterpenoid saponin, cinnamic acid derivates, and deoxypodophyllotoxin ${ }^{[14-17]}$. A previous study has shown that Pulsatilla saponin D isolated from the root of $P$. koreana Nakai had inhibited tumor growth rate on the BDF1 mice bearing Lewis lung carcinoma cells ${ }^{[12]}$. It was reported that methanol extract from $P$. koreana inhibited inflammatory reactions in lipopolysaccharide-exposed rats $^{[18]}$. Another study demonstrated that $P$. koreana ethanol extract (PKEE) has antitumor activities via apoptosis in anaplastic thyroid cancer cells and antiangiogenesis effects by decreasing the expression of hypoxia-inducible factor $1 \alpha$ and vascular endothelial growth factors ${ }^{[19]}$. However, the extract of P. koreana Nakai, itself, has not been yet scientifically investigated for potential antiobesity effects. In this study, we evaluated the antiobesity effects on preadipocyte differentiation of $P$. koreana Nakai extracted by $70 \%$ ethanol in 3T3-L1 cells.

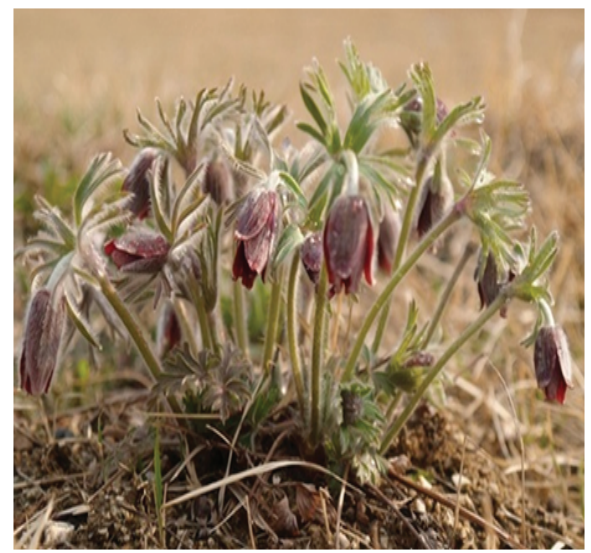

Fig. 1: Representative photograph of Pulsatilla koreana Nakai

\section{MATERIALS AND METHODS}

Dulbecco's modified Eagle's medium (DMEM), bovine calf serum (BCS), fetal bovine serum (FBS), penicillin, streptomycin, and phosphate-buffered saline (PBS) were purchased from Gibco BRL (Grand Island, NY, USA). Dimethyl sulfoxide (DMSO), 1-isobutyl3-methylxanthine (IBMX), dexamethasone, insulin, 3-(4,5 dimethylthiazol-2-yl)-2,5-diphenyltetrazolium bromide (MTT), and oil red $\mathrm{O}$ were purchased from Sigma-Aldrich ChemicalCo.(St.Louis, MO,USA). Cell lysis buffer was obtained from iNtRON Biotechnology Inc. (Seongnam, Korea), and the protein assay reagent was purchased from Bio-Rad Laboratories (Hercules, CA, USA). Polyvinylidene fluoride (PVDF) membrane and chemiluminescence kit were obtained from Amersham Pharmacia Biotech Inc. (NJ, USA). SYBR Green was purchased from Roche Diagnostics Ltd. (Lewes, UK). AntiC/EBP $\alpha$, antiC/EBP $\beta$, antiC/EBP $\delta$, antiPPAR $\gamma$, antiFAS, antiphosphorylated (p)-AMPK $\alpha$, and antiAMPK antibodies were purchased from Cell signal Technology, Inc., (Danvers, MA, USA).

\section{Preparation of plant materials:}

Dried roots of $P$. koreana Nakai were obtained from Kumsan herbal market (Kumsan, Chungnam, Korea). The roots of $P$. koreana Nakai (30 g) were washed and ultrasonically extracted with $300 \mathrm{ml}$ of $70 \%$ ethanol for $2 \mathrm{~h}$. Then, the extract was filtered through a $0.45 \mu \mathrm{m}$ microporous membrane. PKEE so prepared was freeze-dried and stored at $4^{\circ}$ in the dark. When needed it was freshly diluted with distilled water for use in experiments.

\section{Cell maintenance:}

3T3-L1 preadipocytes were purchased from the American Type Tissue Culture Collection (Rockville, $\mathrm{MD}, \mathrm{USA}$ ). Cells were maintained at $37^{\circ}$ in a humidified $5 \% \mathrm{CO}_{2}$ incubator in DMEM supplemented with $10 \%$ BCS and $1 \%$ penicillin-streptomycin until $80 \%$ confluency was reached. To induce differentiating into adipocytes $2 \mathrm{~d}$ after confluency was reached, the cells were incubated in DMEM containing $10 \% \mathrm{FBS}$, $0.5 \mathrm{mM}$ IBMX, $1 \mu \mathrm{M}$ dexamethasone, and $1 \mu \mathrm{g} / \mathrm{ml}$ insulin for $2 \mathrm{~d}$, and then maintained in DMEM containing $10 \% \mathrm{FBS}$ with $1 \mu \mathrm{g} / \mathrm{ml}$ insulin for another 2 d. Fresh DMEM containing $10 \%$ FBS was replaced every $2 \mathrm{~d}$ until the 8 th $\mathrm{d}$.

\section{Cell viability:}

3T3-L1 preadipocytes $\left(2 \times 10^{4}\right.$ cells/well $)$ were seeded 
in 48 well microplates and were treated with 4, 20 and $100 \mu \mathrm{g} / \mathrm{ml}$ of PKEE in a humidified incubator of $5 \%$ $\mathrm{CO}_{2}$ at $37^{\circ}$ for $48 \mathrm{~h}$. At the end of incubation, $50 \mu \mathrm{l}$ of $5 \mathrm{mg} / \mathrm{ml} \mathrm{MTT}$ solution diluted with PBS was added to each well and further incubated at $37^{\circ}$ for $3 \mathrm{~h}$. The medium was removed and $300 \mu \mathrm{l}$ of DMSO added to these wells, and the plates were agitated to dissolve the formed crystal product. Optical density of formazan was measured using a microplate reader (Fluostar Galaxy, BMG Laboratories, Offenburg, Germany) at $540 \mathrm{~nm}$. The readings were compared to the control, which was taken as $100 \%$.

\section{Oil red $O$ staining:}

3 T3-L1 cells were seeded at $3 \times 10^{4}$ cells $/ \mathrm{cm}^{2}$ on 6 -well culture plates. Differentiated 3T3-L1 cells were treated with PKEE at concentrations of 4, 20, and $100 \mu \mathrm{g} / \mathrm{ml}$. Cells were washed twice with PBS and then fixed with $10 \%$ neutral formalin for at least $20 \mathrm{~min}$ at room temperature. After the removal of $10 \%$ neutral formalin, $100 \%$ propylene glycol was added to each well for 3 min. Cells were decolorized with $60 \%$ propylene glycol before staining with the oil red $\mathrm{O}$ working solution and then washed extensively with water. Then, cells were incubated with the oil red $\mathrm{O}$ working solution for $1 \mathrm{~h}$. The stained lipid droplets in 3T3-L1 adipocytes were rinsed three times with distilled water. The staining dye of cells was extracted with isopropyl alcohol and measured spectrophotometrically at $490 \mathrm{~nm}$ using a multi-well plate reader.

\section{Western blot analysis:}

3T3-L1 cells were respectively homogenized in $200 \mu \mathrm{l}$ lysis buffer for $30 \mathrm{~min}$ on ice, and vortexed for $15 \mathrm{~s}$ every $5 \mathrm{~min}$. Lysates were centrifuged at $13000 \mathrm{rpm}$ for $10 \mathrm{~min}$, and supernatants were determined by protein concentration using the Bio-Rad protein assay reagent. Aliquots of $60 \mu \mathrm{g}$ of protein from homogenate were separated by $10 \%$ sodium dodecyl sulphate polyacrylamide gel electrophoresis and then transferred to a PVDF membrane. After blocking for $2 \mathrm{~h}$ with $5 \%$ skim milk, membranes were washed in TBS-T $(0.1 \%$ Tween-20 in 1X TBS) for 10 min four times, and then incubated with primary antibodies (1:2000) derived from rabbit overnight at $4^{\circ}$. After washing with TBS-T, the membranes were incubated with antirabbit IgG or antimouse IgG horseradish peroxidaseconjugated secondary antibodies at 1:5000 diluted in $5 \%$ skim milk in TBS-T for $1 \mathrm{~h}$ at room temperature. At last, immunoactive bands were detected by the chemiluminescence kit using the Fluorchem E image analyser (Cell Biosciences, California, USA).

\section{Ultra performance liquid chromatography (UPLC):}

UPLC separation was performed on an Acquity UPLC system (Waters Corp., Milford, MA, USA) with an Acquity UPLC BEH C18 column $(2.1 \times 50 \mathrm{~mm}, 1.7 \mu \mathrm{m}$ particle size). Temperature of the column was set at $30^{\circ}$ and the mobile phase consisted of acetonitrile (phase A) and $0.1 \% \mathrm{H}_{3} \mathrm{PO}_{4}$ (phase $\mathrm{B}$ ). The gradient was applied with the condition at $0-4.5 \mathrm{~min}(4-10 \% \mathrm{~A}, 96-90 \% \mathrm{~B})$. Two microliters of each working solution was injected into the UPLC instrument to construct the calibration curves. Each mixed standard solution was injected in triplicate. Calibration curves were established by plotting the peak area versus concentration $(\mu \mathrm{g} / \mathrm{ml})$ of each analyte. The limit of detection and limit of quantification for each standard were defined at signalto-noise ratio of 3.3 and 10 , respectively. To confirm the repeatability, three independently prepared samples were analysed.

\section{Statistical analysis:}

All results were statistically analysed by SPSS 19.0 analysis program and presented as mean \pm SD. Data were calculated by using one-way analysis of variance and the post hoc test was performed via the Turkey's test. P-values of less than 0.05 were used as the criterion for statistical significance.

\section{RESULTS AND DISCUSSION}

The 3T3-L1 fibroblast cell line, which is derived from mouse embryonic tissue, has been used to identify key molecular markers, transcription factors and various interactions ${ }^{[4,20]}$. In the current study, the antiadipogenic activity of PKEE on cell viability, transcriptional factors in adipocyte differentiation, and fatty acid synthesis regulation using 3T3-L1 were examined. Treatment with PKEE significantly decreased the contents of intracellular lipid accumulation stained by oil red $\mathrm{O}$ in differentiated adipocytes, regardless of cell toxicity. To evaluate cell viability, 3T3-L1 preadipocytes were treated with various concentrations at a concentration of $\operatorname{PKEE~}(4,20$ and $100 \mu \mathrm{g} / \mathrm{ml})$ for $48 \mathrm{~h}$. The cytotoxicity by PKEE treatment did not alter cell viability at concentrations of 4, 20 and $100 \mu \mathrm{g} / \mathrm{ml}$ (fig. 2). The cytoplasmic lipid accumulation in differentiated adipocytes was examined by oil red $\mathrm{O}$ staining at the end of the 8th $\mathrm{d}$. As shown in fig. $3 \mathrm{~A}$ and $\mathrm{B}$, the content of lipid accumulation in 


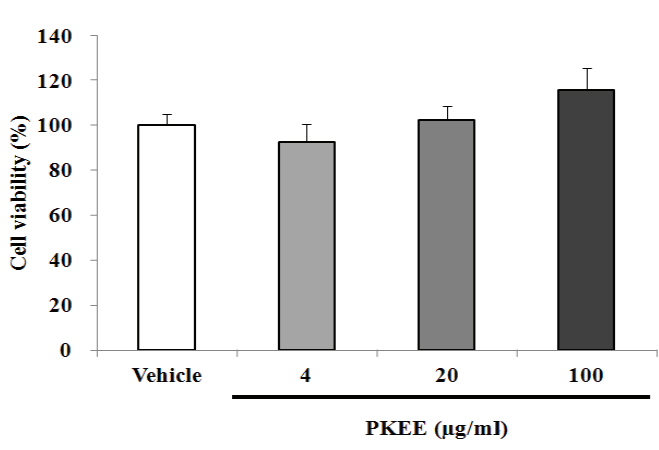

Fig. 2: Cell viability

A.

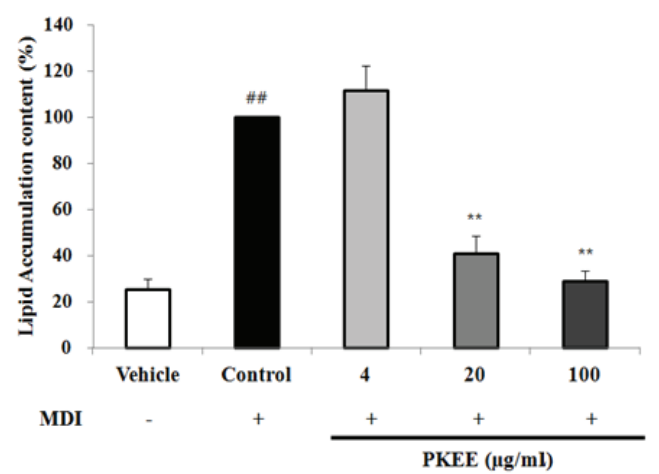

B.

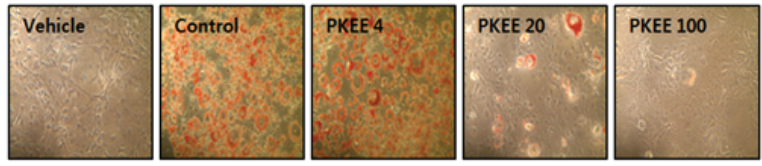

Fig. 3: Contents of lipid accumulation

(A) Effect of PKEE on contents of lipid accumulation and (B) representative image by oil red $O$ staining in 3T3-L1 cells. Vehicle, untreated cells; control, $0.5 \mathrm{mM}$ IBMX, $1 \mu \mathrm{M}$ dexamethasone and $1 \mu \mathrm{g} / \mathrm{ml}$ insulin (MDI) treated cells; PKEE 4, MDI plus $4 \mu \mathrm{g} / \mathrm{ml}$ of PKEE-treated cells, PKEE 20, MDI plus $20 \mu \mathrm{g} / \mathrm{ml}$ of PKEE-treated cells, PKEE 100, MDI plus $100 \mu \mathrm{g} / \mathrm{ml}$ of PKEE-treated cells. ${ }^{\# \#} \mathbf{p}<0.01$ vs. vehicle, ${ }^{* *} \mathbf{p}<0.01$ vs. control

IBMX, dexamethasone, and insulin (MDI)-treated cells significantly increased compared with that of untreated cells $(p<0.01)$. However, the content of lipid drops in PKEE-treated cells was significantly reduced at concentrations of 20 and $100 \mu \mathrm{g} / \mathrm{ml}$, respectively, in comparison to that of adipocytes differentiated cells treated with MDI excluding PKKE $(\mathrm{p}<0.01)$.

Adipocyte differentiation and maturation are intimately related to the occurrence and development of obesity ${ }^{[21]}$. Adipogenesis, which is the whole process of cell differentiation that preadipocytes undergo to become mature adipocytes, is regulated by several transcriptional factors, including C/EBPs and PPARs, and accompanied with changes in cell morphology, gene expression, and hormone sensitivity ${ }^{[22-24]}$. The expression of $\mathrm{C} / \mathrm{EBPs}$ and PPARs in differentiated cells was observed to investigate whether PKEE was associated with regulating transcriptional factors. The effects of PKEE on the expressions of $\mathrm{C} / \mathrm{EBP} \alpha$, $\mathrm{C} / \mathrm{EBP} \beta, \mathrm{C} / \mathrm{EBP} \delta$, and $\operatorname{PPAR} \gamma$ were investigated by western blot analysis. In the process of adipocyte differentiation, $\mathrm{C} / \mathrm{EBP} \beta$ and $\mathrm{C} / \mathrm{EBP} \delta$ were expressed in the early phase of adipocyte differentiation and rapidly induced by the stimulation of hormone signalling ${ }^{[5,7]}$. As shown in fig. 4, the expression of $\mathrm{C} / \mathrm{EBP} \alpha$, $\mathrm{C} / \mathrm{EBP} \beta, \mathrm{C} / \mathrm{EBP} \delta$, and PPAR $\gamma$ in MDI-differentiated cells was significantly increased compared with that of untreated cells without MDI. Especially in adipocytes treated with PKEE at a concentration of $20 \mu \mathrm{g} / \mathrm{ml}$, the expression of $\mathrm{C} / \mathrm{EBP} \alpha$ (fig. $4 \mathrm{~A}$ ), $\mathrm{C} / \mathrm{EBP} \beta$ (fig. 4B), $\mathrm{C} / \mathrm{EBP} \delta$ (fig. 4C), and PPAR $\gamma$ (fig. 4D) were significantly decreased in comparison to adipocytes differentiated by MDI excluding PKKE. After inducing $\mathrm{C} / \mathrm{EBP} \beta$ and $\mathrm{C} / \mathrm{EBP} \delta$ in differentiated cells, they function as transcriptional regulators of $\mathrm{C} / \mathrm{EBP} \alpha$ and $\operatorname{PPAR} \gamma^{[5,7]}$. In the present study, PKEE may decrease the content of lipid accumulation in differentiated cells by downregulating $\mathrm{C} / \mathrm{EBP} \alpha$ and $\mathrm{PPAR} \gamma$ after inhibiting $\mathrm{C} / \mathrm{EBP} \beta$ and $\mathrm{C} / \mathrm{EBP} \delta$ expression. During adipogenesis, $\mathrm{C} / \mathrm{EBP} \alpha$ is involved with stimulating and maintaining PPAR $\gamma$ expression $^{[6,8]}$. PPAR $\gamma$, a nuclear receptor, promotes the expression of a set of genes involved in the maturation of adipocytes ${ }^{[21]}$. Some reports demonstrated that PPAR $\gamma$-mediated lipogenesis in adipose tissue, either directly or indirectly via modulation of the sterol regulatory element-binding protein (SREBP) 1 $\mathrm{c}^{[25,26]}$. $\operatorname{PPAR} \gamma$ and $\mathrm{C} / \mathrm{EBP} \alpha$ synergistically activate the downstream adipocyte-specific gene promoters, such as FAS, acetyl CoA synthase 1, fatty acid transport protein 1 , fatty acid binding protein 4 , and perilipin at the late stage of adipocyte differentiation leading to fat droplet formation ${ }^{[27]}$. Additionally, the expression of FAS, one of lipogenic enzymes was observed in cells to ascertain the inhibitory effects on C/EBPs and PPAR $\gamma$ by PKEE. The amount of FAS expression in PKEE-treated cells was significantly decreased at concentrations of 20 and $100 \mu \mathrm{g} / \mathrm{ml}$, as compared to that of MDI-differentiated cells without PKEE treatment $(p<0.01$; fig. 4E). FAS as a representative key enzyme in the lipogenesis pathway, and plays a role that catalyses all the enzymatic reactions involved in the conversion of acetyl-CoA and malonyl-CoA finally to palmitic acids ${ }^{[9,10]}$. It has been known that FAS causes obesity by increasing the storage of triglycerides ${ }^{[27]}$. In this study, it was assumed that down-regulation of $\mathrm{C} / \mathrm{EBP} \alpha$ expression by PKEE might have decreased fatty acid synthesis along with PPAR $\gamma$ expression, leading to suppression of lipid accumulation. 
A.

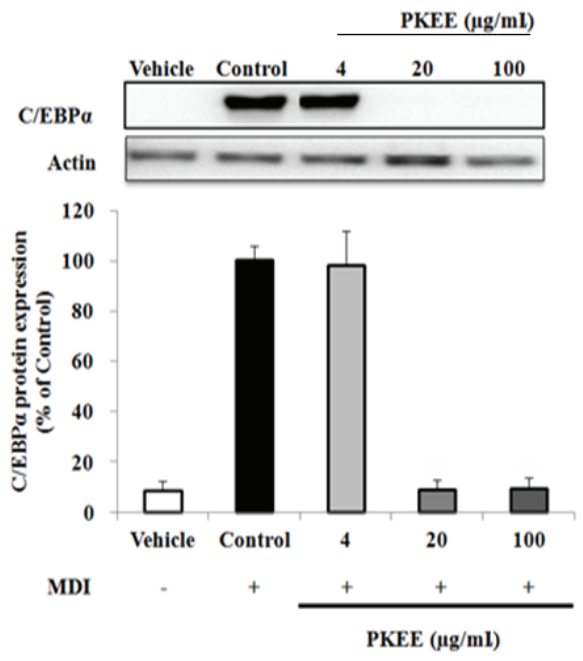

C.

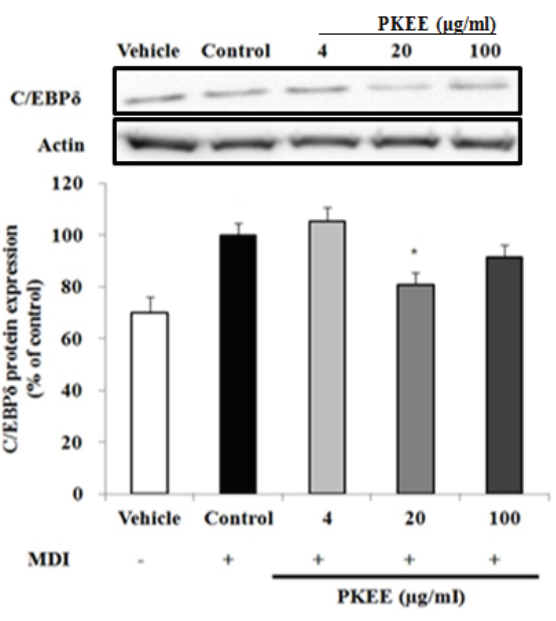

B.

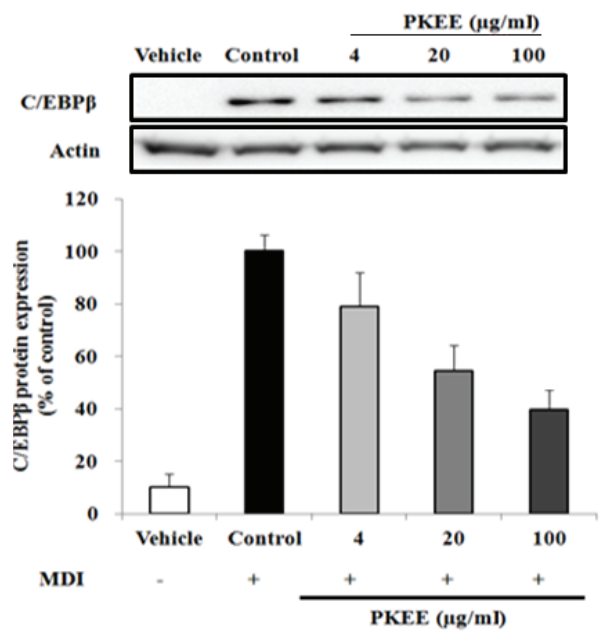

D.
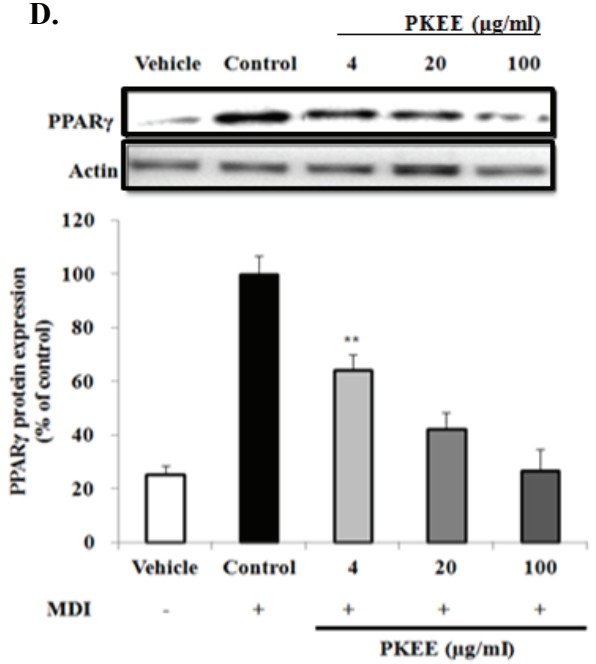

E.

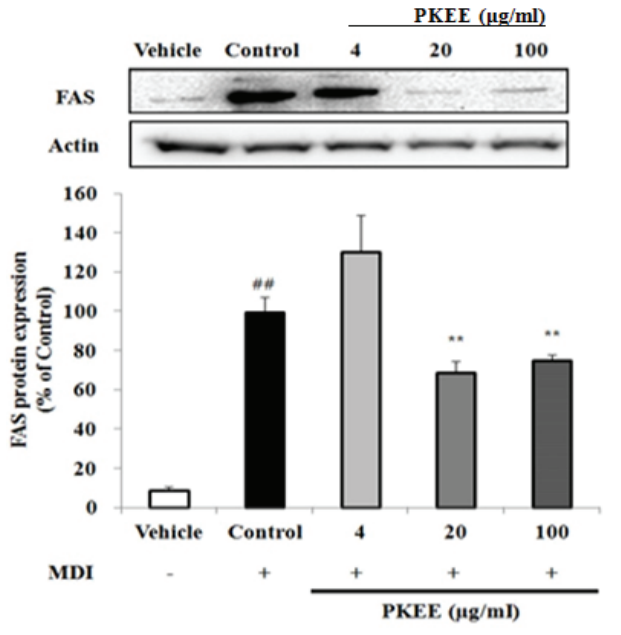

Fig. 4: Protein expressions of C/EBP $\alpha, \mathrm{C} / \mathrm{EBP} \beta, \mathrm{C} / \mathrm{EBP} \delta$, PPAR $\gamma$, and FAS

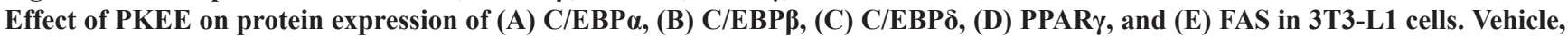
untreated cells; Control, $0.5 \mathrm{mM}$ IBMX, $1 \mu \mathrm{M}$ dexamethasone and $1 \mu \mathrm{g} / \mathrm{ml}$ insulin (MDI) treated cells; PKEE 4, MDI plus $4 \mu \mathrm{g} / \mathrm{ml}$ of PKEE treated cells, PKEE 20, MDI plus $20 \mu \mathrm{g} / \mathrm{ml}$ of PKEE treated cells, PKEE 100, MDI plus $100 \mu \mathrm{g} / \mathrm{ml}$ of PKEE-treated cells. ${ }^{\#} \mathbf{P}<0.01$ vs. vehicle, ${ }^{*} \mathbf{p}<0.01$ vs. control, $* * \mathbf{p}<0.01$ vs. control

Protein levels of p-AMPK $\alpha$, a regulator of target gene such as FAS, were evaluated in adipocytes by western blot analysis. AMPK is a heterotrimeric protein kinase complex that consist of a serine/threonine kinase and 
is an important metabolic sensor that is ubiquitously expressed in almost all eukaryotic cells ${ }^{[28,29]}$. It was reported that AMPK is composed of three subunits, $\alpha$, $\beta$, and $\gamma$, and in mammalian cells there are 2 isoforms of the $\alpha$ subunit, 2 of the $\beta$ subunit, and 3 of the $\gamma$ subunit $^{[30]}$. The activation of AMPK requires the phosphorylation of a critical threonine residue (Thr172) in the activation loop of the $\alpha$-subunit recognized as AMPK $\alpha^{[31]}$. AMPK $\alpha$ can be phosphorylated at Thr172 and Ser485. In this study, $\mathrm{p}$-AMPK $\alpha$ protein expression levels significantly increased with PKEE treatment. AMPK play roles that induce ATP-generation pathways at the intracellular level and couple to phosphorylation of downstream substrates, leading to an increase in the rate of ATP production and a decrease in the rate of ATP utilization $^{[31,32]}$. A previous study demonstrated that not only is AMPK an important target for controlling

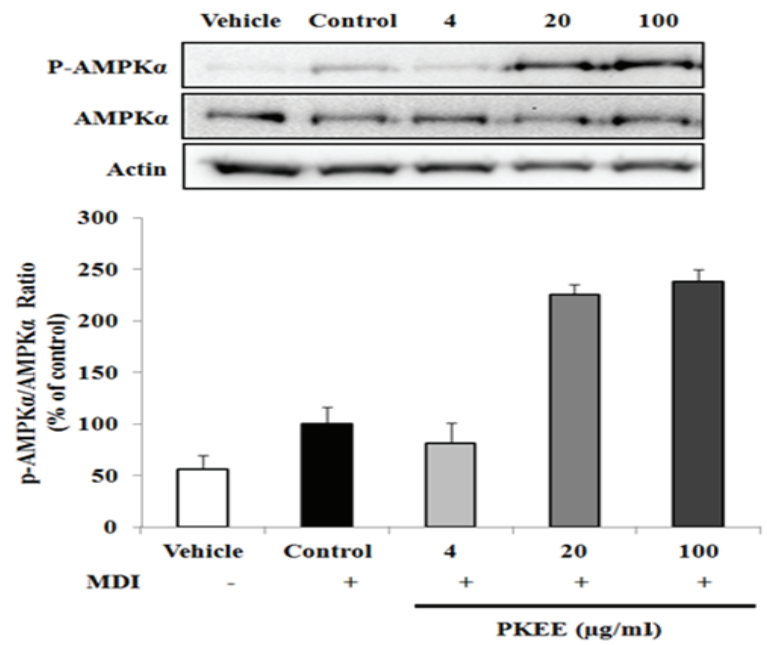

Fig. 5: Protein expressions and phosphorylation of AMPKa

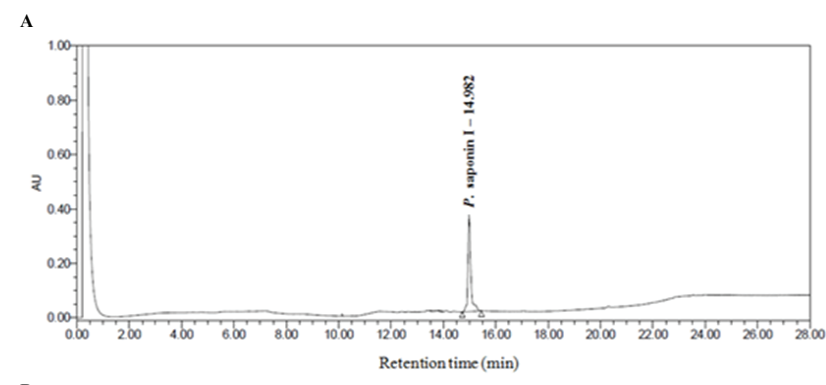

B

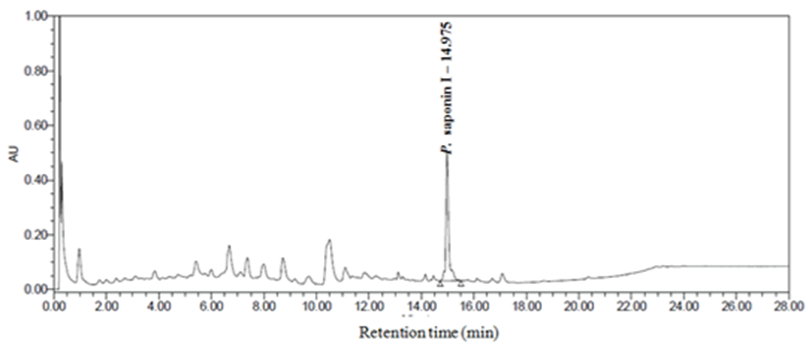

Fig. 6: UPLC chromatograms of (A) P. koreana and (B) PKEE at $206 \mathrm{~nm}$ metabolic diseases, including type 2 diabetes, obesity, and cancers, but also a molecular candidate of controlling adipocyte differentiation ${ }^{[33,34]}$. As shown in fig. 5, PKEE at concentrations of 20 and $100 \mu \mathrm{g} / \mathrm{ml}$ significantly activated the protein expression of $\mathrm{p}$-AMPK $\alpha \quad(\mathrm{p}<0.01)$, although the treatment of PKEE at concentrations of $4 \mu \mathrm{g} / \mathrm{ml}$ had no difference in $\mathrm{p}$-AMPK $\alpha$ level compared to untreated differentiated adipocytes. Additionally, UPLC analysis was carried to identify constituents of PKEE (fig. 6). The compound detected in PKEE was $P$. saponin I (3-O- $\beta$-D-glucopyranosyl $(1 \rightarrow 3)-\alpha-\mathrm{L}-$ rhamnopyranosyl $(1 \rightarrow 2)[\beta$-D-glucopyranosyl $(1 \rightarrow 4)]$ $\alpha$-L-arabinopyranosyl oleanolic acid). The content of $P$. saponin I in PKEE was about $13.6 \%$. Overall, the present study demonstrated that PKEE suppressed adipocyte differentiation via downregulation of $\mathrm{C} / \mathrm{EBPs}$ and PPAR $\gamma$ as early and middle stage regulators of terminal adipocyte differentiation in 3T3L1 cells. Moreover, PKEE decreased the expression levels of FAS and increased activation of AMPK without cytotoxicity in cells. These results suggested that PKEE might be explored as a new preventive and therapeutic agent against obesity.

\section{Conflict of interest:}

The authors report no conflicts of interest in this work.

\section{Financial assistance and scholarship:}

This research was financially supported by the Ministry of Trade, Industry and Energy (MOTIE), Korea Institute for Advancement of Technology (KIAT) through the Encouragement Program for the Industries of Economic Cooperation Region.

\section{REFERENCES}

1. Khan M, Joseph F. Adipose tissue and adipokines: the association with and application of adipokines in obesity. Scientifica 2014;2014:328592.

2. Triscari J, Nauss-Karol C, Levin BE, Sullivan AC. Changes in lipid metabolism in diet-induced obesity. Metabolism 1985;34:580-7.

3. Kolpelman PG. Obesity as a medical problem. Nature 2000;404(6778):635-43.

4. Green H, Kehinde O. An established preadipose cell line and its differentiation in culture. II. Factors affecting the adipose conversion. Cell 1975;5(1):19-27.

5. Cao Z, Umek RM, McKnight SL. Regulated expression of three C/EBP isoforms during adipose conversion of 3T3-Ll cells. Genes Dev 1991;5(9):1538-52.

6. Kim NH, Choi SK, Kim SJ, Moon PD, Lim HS, Choi IY, et al. Green tea seed oil reduces weight gain in $\mathrm{C} 57 \mathrm{BL} / 6 \mathrm{~J}$ mice and influences adipocyte differentiation by suppressing 
peroxisome proliferator-activated receptor- $\gamma$. Pflugers Arch 2008;457:293-302.

7. $\mathrm{Wu} \mathrm{Z}$, Bucher NL, Farmer SR. Induction of peroxisome proliferator-activated receptor gamma during the conversion of 3T3 fibroblasts into adipocytes is mediated by $\mathrm{C} /$ EBPbeta, C/EBPdelta, and glucocorticoids. Mol Cell Biol 1996;16(8):4128-36.

8. Tang QQ, Otto TC, Lane MD. CCAAT/enhancer-binding protein beta is required for mitotic clonal expansion during adipogenesis. Proc Natl Acad Sci USA 2003;100(3):850-5.

9. Ilavenil S, Arasu MV, Lee JC, Kim DH, Vijayakumar M, Lee $\mathrm{KD}$, et al. Positive regulations of adipogenesis by Italian ryegrass [Lolium multiflorum] in 3T3-L1 cells. BMC Biotechnol 2014;14:54.

10. Hillgartner FB, Salati LM, Goodridge AG. Physiological and molecular mechanisms involved in nutritional regulation of fatty acid synthesis. Physiol Rev 1995;75(1):47-76.

11. Nandipati KC, Subramanian S, Agrawal DK. Protein kinases: mechanisms and downstream targets in inflammationmediated obesity and insulin resistance. Mol Cell Biochem 2017;426(1-2):27-45.

12. Kim Y, Bang SC, Lee JH, Ahn BZ. Pulsatilla Saponin D: the antitumor principle from Pulsatilla koreana. Arch Pharm Res 2004;27(9):915-8.

13. Lee KY, Cho YW, Park JH, Lee DY, Kim SH, Kim YC, et al. Quality control of Pulsatilla koreana based on the stimultaneous determination of triterpenoidal saponins by HPLC-ELSD and principal component analysis. Phytochem Anal 2010;21(4):314-21.

14. Bang SC, Kim Y, Lee JH, Ahn BZ. Triterpenoid saponins from the roots of Pulsatilla koreana. J Nat Prod 2005;68(2):268-72.

15. Mimaki Y, Yokosuka A, Kuroda M, Hamanaka M, Sakuma C, Sashida Y. New bisdesmosidic triterpene saponins from the roots of Pulsatilla chinensis. J Nat Prod 2011;64(9):1226-9.

16. Li W, Ding Y, Sun YN, Yan XT, Yang SY, Choi CW, et al. Triterpenoid saponins of Pulsatilla koreana root have inhibition effects of Tumor Necrosis Factor- $\alpha$ secretion in Lipopolysaccharide-induced RAW264.7 cells. Chem Pharm Bull 2013;61(4):471-6.

17. Li W, Ding Y, Sun YN, Yan XT, Yang SY, Choi CW, et al. Oleanane-type triterpenoid saponins from the roots of Pulsatilla koreana and their apoptosis-inducing effects on HL-60 human promyelocytic leukemia cells. Arch Pharm Res 2013;36(6):768-74.

18. Lee SH, Lee E, Ko YT. Anti-inflammatory effects of a methanol extract from Pulsatilla koreana in lipopolysaccharide-exposed rats. BMB Rep 2012;45(6):371-6.

19. Park BH, Jung KH, Son MK, Seo JH, Lee HS, Lee JH, et al. Antitumor activity of Pulsatilla koreana extract in anaplastic thyroid cancer via apoptosis and anti-angiogenesis. Mol Med Rep 2013;7(1):26-30.

20. Green H, Kehinde O. Sublines of mouse $3 T 3$ cells that accumulate lipid. Cell 1974;1:113-6.

21. Rosen ED, Walkey CJ, Puigserver P, Spiegelman BM. Transcriptional regulation of adipogenesis. Genes Dev 2000;14:1293-307.

22. Morrison RF, Farmer SR. Hormonal signalling and transcriptional control of adipocyte differentiation. J Nutr 2000;130(12):3116S-21S.

23. Rosen ED, MacDougald OA. Adipocyte differentiation from the inside out. Nat Rev Mol Cell Biol 2006;7(12):885-96.

24. Birbrair A, Zhang T, Wang ZM, Messi ML, Enikolopov GN, Mintz A, et al. Role of pericytes in skeletal muscle regeneration and fat accumulation. Stem Cells Dev 2013;22:2298-314.

25. Kim JB, Wright HM, Wright M, Spiegelman BM. ADD1/ SREBP1 activates PPAR gamma through the production of endogenous ligand. Proc Natl Acad Sci USA 1998;95(8):4333-7.

26. Farmer SR. Regulation of PPARgamma activity during adipogenesis. Int J Obes 2005;29:13-6.

27. Loftus TM, Jaworsky DE, Frehywot GL, Townsend CA, Ronnett GV, Lane MD, et al. Reduced food intake and body weight in mice treated with fatty acid synthase inhibitors. Science 2000;288:2379-81.

28. Long YC, Zierath JR. AMP-activated protein kinase signalling in metabolic regulation. J Clin Invest 2006;116(7):1776-83.

29. Mihaylova MM, Shaw RJ. The AMPK signalling pathway coordinates cell growth, autophagy and metabolism. Nat Cell Biol 2011;13(9):1016-23.

30. Carling D. The AMP-activated protein kinase cascade-a unifying system for energy control. Trends Biochem Sci 2004;29(1):18-24.

31. Hawley SA, Davison M, Woods A, Davies SP, Beri RK, Carling $\mathrm{D}$, et al. Characterization of the AMP-activated protein kinase kinase from rat liver and identification of threonine 172 as the major site at which it phosphorylates AMP-activated protein kinase. J Biol Chem 1996;271(44): 27879-87.

32. Feng Y, Liu JQ, Liu HC. AMP-activated protein kinase acts as a negative regulator of high glucose-induced RANKL expression in human periodontal ligament cells. Chin Med J 2012;25:3298-304.

33. Fryer LG, Parbu-Patel A, Carling D. The Anti-diabetic drugs rosiglitazone and metformin stimulate AMP-activated protein kinase through distinct signalling pathways. J Biol Chem 2002;277(28):25226-32.

34. Krycer JR, Sharpe LJ, Luu W, Brown AJ. The Akt-SREBP nexus: cell signalling meets lipid metabolism. Trends Endocrinol Metab 2010;21(5):268-76. 